\title{
PERENCANAAN STRUKTUR BAWAH JEMBATAN DAERAH PERBUKITAN KECAMATAN SEMENDO DARAT TENGAH KABUPATEN MUARA ENIM
}

\author{
Hariman Al Faritzie, Bahder Djohan, Muhammad Ali Hastila \\ Jurusan Teknik Sipil, Fakultas Teknik, Universitas Tridinanti Palembang \\ Jl. Kapten Marzuki No. 2446 Kamboja, Palembang 30129
}

\begin{abstract}
ABSTRAK
Jembatan merupakan suatu konstruksi yang berfungsi untuk menghubungkan dua bagian jalan yang terputus oleh adanya rintangan-rintangan seperti lembah yang dalam, alur sungai, danau, saluran irigasi, kali, jalan kereta api, jalan raya yang melintang tidak sebidang, dan lain sebagainya. Di desa Batu Surau Kecamatan Semendo Darat Tengah Kabupaten Muara Enim merupakan daerah perbukitan dengan kemiringan lereng landai hingga terjal dan juga jenis tanah dengan batuan keras, sehingga tidak bias menggunakan pondasi tiang pancang pada daerah ini. Adapun tujuan dari penelitian ini untuk mengetahui perhitungan desain abutment daerah perbukitan dan untuk mengetahui perhitungan desain pondasi sumuran daerah perbukitan kecamatan Semendo Darat Tengah Kabupaten Muara Enim. Data primer yang diambil pada penelitian ini adalah data Pengukuran Topografi yang di ukur langsung dilapangan, sampel tanah yang di ambil hasil uji Sondir dan hasil uji Hand Boring pada Laboratorium. Data sekunder berupa peta system jaringan jalan, data lalulintas harian rata-rata, data hidrologi dan peta zona gempa Indonesia yang di dapat dari Dinas Pekerjaan Umum dan Penataan Ruang Kabupaten Muara Enim. Dari hasil penelitian didapatkan hasil dimensi abudment I dengan tinggi 12,2 meter, panjang 10 meter dan lebar 11,3 meter sedangkan abudment II dengan tinggi 13,4 meter, panjang 10 meter dan lebar 12,5 meter. Dan didapatkan hasil dimensi pondasi sumuran sesuai dengan hasil uji sondir dengan daya dukung $2500 \mathrm{Kn}$ di kedalaman 5 meter dan hand boring dengan berat jenis tanah $1,441 \mathrm{Gr} / \mathrm{cm} 3$, sudut geser $15,87^{\circ}$ dan Kohesi sebesar $0,125 \mathrm{Kg} / \mathrm{cm} 2$ maka didapatkan dimensi pondasi sumuran I dengan tinggi 3,5 meter dan lebar 3,0 meter dengan jumlah pondasi 2 buah sedangkan dimensi pondasi sumuran I dengan tinggi 3,5 meter dan lebar 3,2 meter dengan jumlah pondasi 2 buah.
\end{abstract}

Kata kunci : Jembatan, Desa Batu Surau, Semendo, Muara Enim, Abudment, Topografi, Pondasi.

\section{PENDAHULUAN}

Jembatan adalah suatu bangunan yang memungkinkan suatu jalan menyilang saluran air, lembah atau menyilang jalan lainnya yang tidak sama tinggi permukaannya dan lalu-lintas itu tidak terputus karenanya (Imam Subarkah, 1979). Jembatan merupakan alat penghubung atau alat perhubungan antar daerah yang penting sekali bagi masyarakat dan pemerintah yang menunjang perekonomian, sosial, perdagangan dan lainnya, kerusakan pada jembatan dapat menimbulkan gangguan terhadap kelancaran lalu-lintas, terlebih dijalan yang lalu lintasnya padat sehingga struktur jembatan harus di rencanakan kuat, kokoh dan tahan terhadap kondisi alam seperti struktur tanah yang labil, gempa dan angin. Namun demikian tidak berarti bahwa jembatan harus di buat lebih kokoh dan lebih kuat secara berlebihan, untuk itu menggunakan kontruksi jembatan yang paling ekonomis, baik kekuatan, bahan-bahan dan proses pembangunannya

Penelitian ini bertujuan untuk mengetahui perhitungan desain abutment daerah perbukitan kecamatan Semendo Darat Tengah Kabupaten Muara Enim serta mengetahui perhitungan desain pondasi sumuran daerah perbukitan kecamatan Semendo Darat Tengah Kabupaten Muara Enim.

Jembatan merupakan suatu konstruksi yang berfungsi untuk menghubungkan dua bagian jalan yang terputus oleh adanya 
rintangan-rintangan seperti lembah yang dalam, alursungai, danau, saluran irigasi, kali, jalan keretaapi, jalan raya yang melintang tidak sebidang, dan lain sebagainya. Selain menjadi penghubung, jembatan juga dijadikan icon suatu kota. Klasifikasi tipe struktur jembatan secara umum ada 6 tipe sebagai berikut :
1. Jembatan Gelagar
2. Jembatan Pelengkung
3. Jembatan rangka
4. Jembatan Portal
5. Jembatan Gantung
6. Jembatan Kabel

\section{Pondasi Jembatan}

Pondasi adalah suatu konstruksi pada bagian dasar struktur/banguan (substructure) yang berfungsi meneruskan beban dari bagian atas struktur/bangunan (upper-structure) kelapisan tanah yang berada di bagian bawahnya tanpa mengakibatkan keruntuhan geser tanah dan penurunan (settlement) tanah/fondasi yang berlebihan. Beberapa bangunan dapat dibangun karena pondasi merupakan komponen utama dari suatu bangunan termasuk jembatan. Pondasi jembatan adalah bagian dari jembatan yang berfungsi memikul seluruh beban yang bekerja pada pilar atau kepala jembatan dan gaya-gaya lainnya serta melimpahkannya kelapisan tanah pendukung.

Persyaratan utama pondasi adalah sebagai berikut:

1. Cukup kuat menahan muatan geser akibat muatan tegak kebawah.

2. Dapat menyesuaikan pergerakan tanah yang tidak stabil (tanah gerak).

3. Tahan terhadap pengaruh perubahan cuaca.

4. Tahan terhadap pengaruh bahan kimia.

\section{Abutment Jembatan}

Pangkal jembatan/abutment adalah bangunan bawah jembatan yang terletak pada kedua ujung jembatan, berfungsi sebagai pemikul seluruh beban pada ujung luar batang, pinggir dan gaya-gaya lainnya, serta melimpah ke pondasi. Apabila daya dukung tanah yang terdapat di bawah abutment tidak memenuhi maka daya dukungnya harus ditambah dengan pondasi dalam (pondasi sumuran, pondasi caisson). Adapun jenis pondasi yang digunakan adalah tergantung dari jenis tanah yang ada di bawah struktur tersebut. Abutment / pangkal jembatan dapat diasumsikan sebagai dinding penahan tanah, yang berfungsi menyalurkan gaya vertikal dan horizontal dari bangunan atas ke pondasi dengan fungsi tambahan untuk mengadakan peralihan tumpuan dari oprit ke bangunan atas jembatan

\section{Perhitungan Perencanaan Abutment dan Pondasi Sumuran}

Perhitungan perencanaan merupakan tahapan yang sangat penting untuk suatu kontruksi jembatan sehingga didapatkan konstruksi yang kuat serta efisien baik dari segi biaya dan waktu pelaksanaan. Perhitungan perencanaan antara lain perencanaan abutment dan perencanaan pondasi sumuran.

\section{Perencanaan Abutment}

Menurut Standar Pembebanan untukJ embatan, RSNI T-02-2005, Analisis abutment yang akan di hitung meliputi :

1. Berat Sendiri Struktur Bawah (Mms), Jumlah dari

a) Berat sendiri abutment $=\mathrm{b} \times \mathrm{t} \times \mathrm{L} \times \mathrm{w}$

b) Berat sendiri Wingwall $=\mathrm{b} \times \mathrm{t} \times \mathrm{L} \times \mathrm{w}$

............... (3.2)

c) Tanah $=\mathrm{n} \times \mathrm{L} \times \mathrm{w} \ldots \ldots$ (3.3)

2. Beban Total Akibat Berat Sendiri (MS) Ms $=$ Mms Strukturatas + Mms Struktur Bawah

\section{Beban Mati Tambahan}

Beban mati tambahan adalah berat seluruh bahan yang menimbulkan suatu beban pada jembatan yang merupakan elemen nonstruktural dan mungkin besarnya berubah selama umur jembatan. Jembatan dianalisis harus mampu memikul beban tambahan seperti lapisan aspal dikemudian hari, genangan air hujan jika system drainase tidak bekerja dengan baik, pemasangan tiang listrik dan instalasi mekanikal dan listrik

Berat Mati Tambahan (Wma) merupakan jumlah dari :

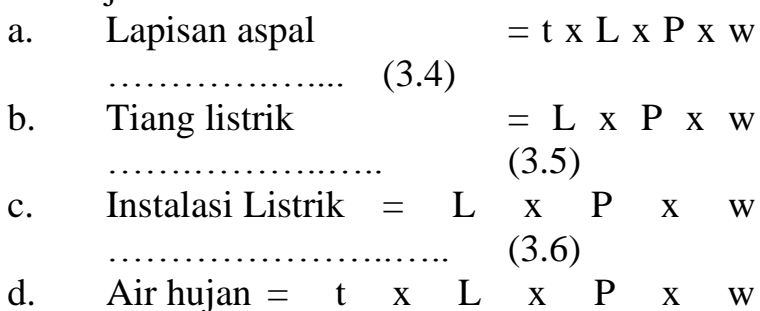
(3.7)

Beban pada abutment akibat beban mati tambahan, 
PMA $=1 / 2 *$ WMA

Eksentrisitas beban thd. Fondasi, e = -

$\mathrm{Bx} / 2+\mathrm{b} 8+\mathrm{b} 7 / 2(3.9)$

Momen pada fondasi akibat berat sendiris truktur atas,

$\mathrm{MMA}=\mathrm{PMA} * \mathrm{e}$.

4. Tekanan Tanah

Tekanan tanah lateral dihitung berdasarkan harga nominal dari berat tanah (Ws), sudut gesek dalam $(\phi)$ dan kohesi (c) dengan :

$$
\begin{aligned}
& \text { Ws' }=\text { Ws } \ldots \ldots \ldots \ldots \ldots . \\
& \phi^{\prime}=\tan ^{-1}\left(\mathrm{~K}_{\phi}{ }^{\mathrm{R}} * \tan \phi\right) \\
& \mathrm{c}^{\prime}=\mathrm{K}_{\mathrm{c}}{ }^{\mathrm{R}} * \mathrm{c}
\end{aligned}
$$

Koefisien tekanan tanah aktif,

\section{Beban Lajur "D" (TD)}

Beban Kendaraan yang berupa beban lajur "D" terdiri dari beban terbagi merata (Uniformly Distributed Load), UDL dan beban garis (Knife Edge Load), KEL seperti pada gambar 1. UDL mempunyai intensitas $\mathrm{q}(\mathrm{kPa})$ yang besarnya tergantung lalu lintas atau seperti gambar 2 dinyatakan dengan rumus sebagai berikut :

$$
\begin{array}{ll}
\mathrm{q}=8.0 & \mathrm{kPa} \\
\mathrm{q}=8.0 *(0.5+15 / \mathrm{L}) & \mathrm{kPa}
\end{array}
$$

\section{Beban Pedestrian / Pejalan Kaki (TP)}

Jembatan jalan raya direncanakan mampu memikul beban hidup merata pada trotoar yang besarnya tergantung pada luas bidang trotoar yang didukungnya

$\mathrm{A}=$ luas bidang trotoar yang dibebani pejalan kaki (m2)

Beban hidup merata $\mathrm{q}$ :

Untuk $\mathrm{A} \leq 10 \mathrm{~m} 2$ :

$$
\begin{aligned}
& \mathrm{q}=5 \mathrm{kPa} \\
& \text { Untuk } 10 \mathrm{~m} 2<\mathrm{A} \leq 100 \mathrm{~m} 2: \\
& \mathrm{q}=5-0.033^{*}(\mathrm{~A}-10) \mathrm{kPa} \\
& \text { Untuk } \mathrm{A}>100 \mathrm{~m} 2: \\
& \mathrm{q}=2 \mathrm{kPa}
\end{aligned}
$$

\section{Gaya Rem (TB)}

Pengaruh pengereman dari lalu-lintas diperhitungkan sebagai gaya dalam arah memanjang, dan dianggap bekerja pada permukaan lantai jembatan. Besarnya gaya rem arah memanjang jembatan tergantung panjang total jembatan (Lt) sebagai berikut :

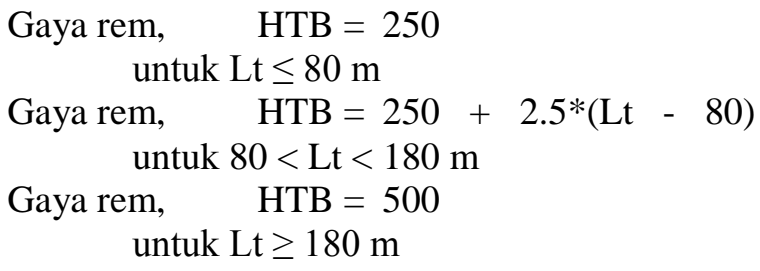

8. Pengaruh Temperatur

Untuk memperhitungkan tegangan maupun deformasi struktur yang timbul akibat pengaruh temperatur, diambil perbedaan temperatur yang besarnya setengah dari selisih antara temperature maksimum dan temperatur minimum ratarata pada lantai jembatan.

$\Delta \mathrm{T}=(\mathrm{Tmax}-\mathrm{Tmin}) / 2$

Dengan :

Tmax : Temperatur maksimum rata-rata

Tmin : Temperatur minimum rata-rata

9. Beban angin (EW)

Gaya akibat angin yang meniup bidang samping jembatan dihitung dengan rumus :

TEW1 = $0.0006 * \mathrm{Cw} *(\mathrm{Vw}) 2 * \mathrm{Ab}$

$\mathrm{CW}=$ Koefisien seret

$\mathrm{VW}=$ kecepatan angina rencana $(\mathrm{m} / \mathrm{det})$

$\mathrm{Ab}=$ luas bidang samping jembatan $(\mathrm{m} 2)$

10. Beban Gempa (EQ)

a) Beban gempa static ekivalen

Beban gempa rencana dihitung dengan rumus : $\mathrm{TEQ}=\mathrm{Kh} * \mathrm{I} * \mathrm{Wt}$

Dengan, $\quad \mathrm{Kh}=\mathrm{C} * \mathrm{~S} \ldots \ldots \quad(3.14)$

TEQ = Gaya geser dasar total pada arah yang ditinjau $(\mathrm{kN})$

$\mathrm{Kh}=$ Koefisien beban gempa horisontal

I = Faktor kepentingan

$\mathrm{Wt}=$ Berat total jembatan yang berupa berat sendiri dan beban

Mati tambahan = PMS + PMA

$\mathrm{C}=$ Koefisien geser dasar untuk wilayah gempa, waktu getar dan kondisi tanah

$\mathrm{S} \quad=$ Faktortipestruktur yang berhubungan dengan kapasitas penyerapan energy gempa (daktilitas) dari struktur jembatan

Waktu getar struktur dihitung dengan rumus :

$\mathrm{T}=2 * \pi * \sqrt{ }[\mathrm{WTP} /(\mathrm{g} * \mathrm{KP})]$

(3.15)

$\mathrm{G}=$ percepatan gravitasi $(9.8 \mathrm{~m} / \mathrm{det} 2)$

$\mathrm{KP}=$ kekakuan struktur yang merupakan 
gaya horisontal yang diperlukan untuk menimbulkan satu satuan lendutan $(\mathrm{kN} / \mathrm{m})$

WTP $=$ PMS (str atas) $+1 / 2 *$ PMS (str bawah)

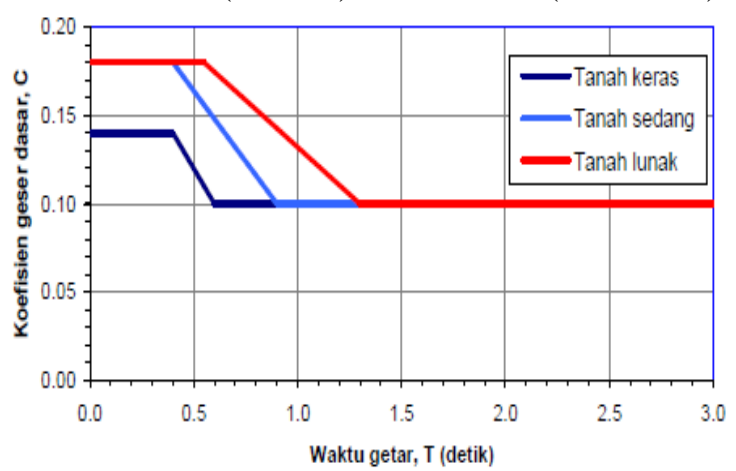

Gambar 2.5 Hubungan waktu getar struktur

b) Tekanan tanah dinamis akibat gempa

Gaya gempa arah lateral akibat tekanan tanah dinamis dihitung dengan menggunakan koefisian tekanan tanah dinamis $(\Delta \mathrm{KaG})$ sebagai berikut :

$\theta=\tan -1(\mathrm{Kh})$

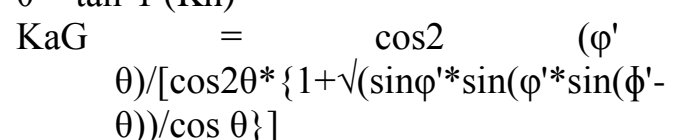

$\Delta \mathrm{KaG}=\mathrm{KaG}-\mathrm{Ka}$

Tekanan tanah dinamis,

$\mathrm{p}=\mathrm{Hw}^{*} \mathrm{Ws} * \Delta \mathrm{KaG}$

11. Gesekan pada perletakan (FB)

Koefisien gesek pada tumpuan yang berupa elastomer

Reaksi abutment akibat beban tetap, PT = PMS+PMA ...... (3.18)

Gaya gesek pada perletakan, $\mu * \mathrm{PT}$

$\mathrm{TFB}=$

12. Kontrol stabilitas guling

12.1. Stabilitas guling arah $\mathrm{x}$

Angka aman (SF) terhadap guling cukup diambil $=2.2$

Letak titik guling A (ujung fondasi) thd. Pusat fondasi $=\mathrm{Bx} / 2$

Momen penahan guling, Mpx = $\mathrm{P} *(\mathrm{Bx} / 2) *(1+\mathrm{k}) \ldots \ldots \ldots .(3.20)$

Angka aman terhadap guling,

$\mathrm{SF}=\mathrm{Mpx} / \mathrm{Mx}$

harus $\geq 2.2$

Dimana,

$\mathrm{k} \quad=$ persen kelebihan beban yang diijinkan (\%)

$\mathrm{Mx}=$ momen penyebab guling $\operatorname{arah} \mathrm{x}$
12.2. Stabilitas guling arah y

Letak titik guling A (ujung fondasi) thd.

Pusat fondasi : By / 2

Momen penahan guling,

$\mathrm{Mpy}=\mathrm{P} *(\mathrm{By} / 2) *(1+\mathrm{k})$

Angka aman terhadap guling,

$\mathrm{SF}=\mathrm{Mpy} / \mathrm{My}$

harus $\geq 2.2$

Dimana,

$\mathrm{k}=$ persen kelebihan beban yang diijinkan $(\%)$

$\mathrm{Mx}=$ momen penyebab guling arah $\mathrm{y}$

13. Kontrol stabilitas geser

13.1. Stabilitas geser arah $x$

Gaya penahan geser,

$\mathrm{H}=(\mathrm{C} * \mathrm{Bx} * \mathrm{By}+\mathrm{P} * \tan \varphi) *(1+\mathrm{k})$

$\mathrm{H}$ harus $\geq 1,1$

Dimana,

$\mathrm{k}=$ persen kelebihan beban yang diijinkan $(\%)$

$\mathrm{Tx} \quad$ = gaya penyebab geser

13.2. Stabilitas geser arah y

Gaya penahan geser,

$\mathrm{H}=(\mathrm{C} * \mathrm{Bx} * \mathrm{By}+\mathrm{P} * \tan \varphi) *(1+\mathrm{k}) . .(3.22)$

$\mathrm{H}$ harus $\geq 1,1$

Dimana,

$\mathrm{k}=$ persen kelebihan beban yang diijinkan

(\%)

$\mathrm{Tx}=$ gaya penyebab geser

14. Perhitungan bangunan pelengkap abutment

Selain perhitungan diatas, perlua juga perhitungan lainnya yaitu :

a. Dinding penahan (breast wall)

Kontruksi ini harus mampu menerima gaya horizontal akibat tekanan tanah aktif dan tekanan tanah pasif, gaya gempa, serta seluruh gaya vertical yang bekerja. Analisis yang dilakukan yaitu :

1) Berat sendiri (MS)

2) Tekanan tanah (TA)

3) Beban Gempa

b. Dinding belakang (back wall)

Merupakan kontruksi dinding yang berfungsi sebagai pembatas antara gelagar dengan tanah belakang abutment. Selain itu juga, parapet berfungsi sebagai penahan gelagar agar tidak bergeser kearah belakang abutment yang terdiri dari : 
1) Backwall atas

2) Backwall bawah

c. Konsol pendek untuk jacking (corbel)

Pada saat penggantian bearing pad (elastomeric), corbel direncanakan mampu menahan jacking force yang terdiri dari berat sendiri struktur atas, beban mati tambahan dan beban lalulintas.

Gaya geser pd Corbel,

Pjack $=\mathrm{P}_{\mathrm{MS}}+\mathrm{P}_{\mathrm{MA}}+\mathrm{P}_{\mathrm{TD}} \ldots \ldots$.

\section{d. Dinding sayap (wing wall)}

Kontruksi ini berfungsi melindungi bagian belakang abutment dari tekanan tanah yang bekerja

Plat wing wall dianalisis sebagai Two Way Slab mengingat salah satu sisi vertical atau horizontal terjepit pada abutment, sehingga terjadi momen pada jepitan yaitu Mx dan My.

$\mathrm{Mx}=1 / 2 *$ Mjepit arah $\mathrm{x}$

My $=1 / 2 *$ Mjepit arah y

\section{Penulangan Abutment}

Penulangan abutment menurut SNI T-122004, yaitu

a. Penulangan badan abutment

Beban yang digunakan dalam penulangan badan abutment diambil dari kombinasi pembebanan yang menghasilkan beban dan momen terbesar.

b. Penulangan kepala abutment

c. Penulangan Poer

\section{Perencanaan Pondasi Sumuran}

Pondasi sumuran adalah pondasi yang dibangun dengan menggali cerobong tanah berpenampang lingkaran dan dicor dengan beton atau campuran batu dan mortar.

Pondasi sumuran merupakan pondasi peralihan antara pondasi dangkal dan pondasi tiang, digunakan bila tanah dasar yang kuat terletak pada kedalaman yang relative dalam, dimana pondasi sumuran nilai kedalaman (Df) dibagi lebar (B) lebih kecil atau sama dengan 4, sedangkan pondasi dangkal $\mathrm{Df} / \mathrm{B} \leq 1$.

Analisis pondasi sumuran yang akan di hitung meliputi :

1. Berat sendiri pondasi sumuran

Berat sendiri pondasi sumuran dihitung sebagai berikut
$P=\frac{\pi D^{2}}{4} \cdot L \cdot 24 \ldots \ldots \ldots \ldots \cdots$

2. Tekanantanahaktif

a. Lapisan 1 (tanah urugan)

Tekanan tanah aktif dari lapisan 1 (tanah urugan) sudah termasuk kedalam gaya-gaya pada dasar pile cap.

b. Lapisan 2

Koefisien tekanan tanah aktif dihitung dengan rumus

$$
\begin{aligned}
& K_{a}=\frac{1-\sin \varphi}{1+\sin \varphi} \ldots \ldots \ldots \ldots \ldots \\
& \mathrm{Q}=\Upsilon 1 * \mathrm{~h} 1 * \mathrm{Ka}+\mathrm{q} \mathrm{Ka}-2 \mathrm{c} \sqrt{\mathrm{Ka}} . .
\end{aligned}
$$

\section{Tekanan tanah pasif}

Lapisan 1 tidak memberikan sumbangan terhadap tekanan tanah pasif

Koefisien tekanan tanah pasif dalam keadaan diam untuk lapisan 2 dihitung sebagai Ko $=1-$ $\sin \phi$

Tekanan tanah pasif keadaan diam pada lapisan 2

$$
\mathrm{q}=2 \mathrm{c} \sqrt{\mathrm{Ko}}
$$

\section{Gaya-gaya bekerja}

Gaya-gaya yang bekerja pada pondasi sumuran ditampilkan dalam bentuk table sehingga didapat total gaya vertical, gaya horizontal aktif\&pasif dan momen.

5. Kestabilan terhadap guling

Kestabilan pondasi sumuran terhadap kemungkinan terguling dihitung dengan persamaan berikut :

$\mathrm{SF}_{\text {guling }}=\frac{\Sigma \mathrm{M}_{\mathrm{R}}}{\Sigma \mathrm{M}_{\mathrm{o}}} \ldots \ldots \ldots \ldots \ldots \ldots$

Nilai minimum dari angka keamanan terhadap guling yang lazim digunakan dalam perencanaan adalah 2.20.

6. Kestabilan terhadap geser

Ketahanan struktur terhadap kemungkinan struktur bergeser dimana nilai $\phi_{2}$ biasanya diambil sama dengan $\phi$ tanah untuk beton pondasi yang di cor di tempat dan $2 / 3$ dari nilai $\phi$ tanah untuk pondasi beton pracetak dengan permukaan halus. Sedangkan nilai $\mathrm{c}_{2}$ 
biasanya diambil 0.4 dari nilai kohesi $\mathrm{c}$ tanah.

$$
\mathrm{SF}_{\text {geser }}=\frac{(\Sigma \mathrm{V}) \tan \varnothing_{2}+\mathrm{Bc}_{2}+\mathrm{P}_{\mathrm{p}}}{\mathrm{P}_{\mathrm{h}}}
$$

Nilai minimum dari Angka Keamanan terhadap geser yang lazim digunakan dalam perencanaan adalah 2.20

\section{Tegangan pada tanah dasar}

Teori yang berkaitan dengan perhitungan daya dukung pondasi dapat diambil dari metode Meyerhf. Untuk memudahkan analisis, bentuk sumuran berupa lingkaran dengan diameter D dapat di ekivalensikan menjadi bentuk empat persegi dengan dimensi B x B. Besarnya nilai B dihitung sebagai berikut:

$B=\sqrt{\frac{\pi * D^{2}}{4}}$

Hal pertama yang perlu diperiksa adalah eksentrisitas dari gaya-gaya ke pondasi dengan menggunakan persamaan berikut

$e k s=\frac{B}{2}-\frac{M_{\text {net }}}{\sum V}$

Tegangan kontak ketanah dasar dihitung dengan persamaan berikut:

$q_{\min }^{\operatorname{mak}}=\frac{\sum V}{B}\left(1 \pm \frac{6 * e k s}{B}\right) \ldots \ldots \ldots$

Jika nilai eksentrisitas beban eks> B/6 maka tegangan kontak minimum q min akan lebih kecil dari 0 .

\section{METODOLOGI PENELITIAN Pengumpulan Data}

Metode Pengumpulan data yang dilakukan adalah sebagai berikut :

Data primer yaitu data yang dibuat oleh peneliti untuk maksud khusus menyelesaikan permasalahan yang sedang ditanganinya. Data dikumpulkan sendiri oleh peneliti langsung dari sumber pertama atau tempat objek penelitian dilakukan.

Data sekunder yaitu data yang telah dikumpulkan untuk maksud selain menyelesaikan masalah yang sedang dihadapi. Data ini dapat ditemukan dengan cepat. Dalam penelitian ini yang menjadi sumber data sekunder adalah literatur, artikel, jurnal
Pengukuran Topografi bertujuan untuk mengetahui beda tinggi permukaan tanah sehingga dapat menentukan bentang dan posisi jembatan. Peralatan yang digunakan antara lain peta rencana trase jalan diatas peta topografi skala $1: 50.000$ atau skala $1: 25.000$, GPS navigasi, heling meter / clino meters, kompas, formulir survey dan calculator, GPS navigasi dan kompas.

Pengujian Sondir atau cone penetration test (CPT) merupakan salah satu pengujian lapangan yang bertujuan untuk mengetahui profil atau pelapisan (stratifikasi) tanah dan daya dukungnya.

Pengujian Bor Tangan (Hand Boring) Pengambilan contoh tanah bertujuan untuk penyelidikan laboratorium. Pengambilan contoh tanah dikerjakan dengan cara contoh tanah tidak terganggu (Undisturbed sample) dengan jumlah yang disesuaikan dengan kebutuhan.

\section{HASIL DAN PEMBAHASAN}

Hasil Uji Sondir (Cone Penetration Test)

Data yang digunakan untuk menganalisis daya dukung tanah dibawah abutment 02 yaitu data hasil uji sondir 1. Hali ini disebabkan letak abudment yang akan dibangun terletak disekitar titik uji Sondir 1. Berikut hasil uji penyelidikan tanah pada titik S1 untuk uji sondir daya dukung hasil uji sondir memiliki nilai sebesar $2500 \mathrm{Kn}$ pada kedalaman 5 meter, dibawah ini merupakan table pembacaan manometer pada uji sondir.

\section{Hasil Uji Hand Boring}

Pengujian hand boring dalam pengambilan contoh tanah tidak terganggu (undisturbed sample) pada titik HB 01, setelah dilakukan uji laboratorium didapatkan :

Dari data diatas digunakan dalam perhitungan tekanan tanah (lampiran 1.1 - 8).

Tekanan tanah lateral dihitung berdasarkan harga nominal dari berat tanah (Ws), sudut gesek dalam $(\phi)$ dan kohesi (c) dengan :

$$
\begin{aligned}
\Phi^{\prime} & =\tan ^{-1}\left(\mathrm{~K}_{\phi}^{\mathrm{R}} * \tan \phi\right) \\
& =0.3203 \mathrm{rad}=18.3491^{\circ} \\
\mathrm{Ka} \quad & =\tan ^{2}\left(45^{\circ}-\phi^{\prime} / 2\right) \\
& =0.5211 \\
\text { Maka } & \text { didapatkan Momen Tekanan Tanah } \\
\text { sebesar } & 31129.78 \mathrm{kNm}
\end{aligned}
$$




\section{Pengukuran Topografi}

Dari peta topografi diatas didapatkan kemiringan permukaan eksisting yang cukup dalam maka dapat ditentukan tinggi abudment sesuai dengan standar kemiringan yang ditentukan sebesar maksimal $8 \%$, sehingga didapat ketinggian abudment I sebesar 12,2 m dan abudment II sebesar 13,4 $\mathrm{m}$.

\section{Beban gempa}

Berdasarkan peta gempa puslitbang Jalan dan Jembatan Pekerjaan Umum, lokasi penelitian di desa Batu Surau kecamatan Semendo Darat Tengah dengan koordinat Latitude $-4.138^{\circ}$ dan Longitude $103.59^{\circ}$ memiliki respons spectra percepatan pada 0.2 detik, SS $=0,579 \mathrm{~g}$ dan respons spectra percepatan pada 1 detik, $\mathrm{S} 1=$ $0.321 \mathrm{~g}$. Jenis tanah termasuk tanah Batuan. Kelas situs adalah SB (Batuan) dengan koefisien geser dasar $(C)=0.269$ termasuk di wilayah gempa 5

Dari data gempa tersebut untuk melengkapi perhitungan beban gempa (lampiran $1.1-15$ ) . Maka didapatkan perhitungan beban gempa static ekivalen

Beban gempa rencana dihitung:

TEQ $=\mathrm{Kh} * \mathrm{I} * \mathrm{Wt}=0.245 * \mathrm{Wt}$

Waktu getar struktur dihitung:

$\mathrm{T} \quad=2 * \pi * \sqrt{[\mathrm{WTP} /(\mathrm{g} * \mathrm{KP})]}$

$$
=0.11 \text { detik }
$$

Tekanan tanah dinamis akibat gempa

$\theta=\tan ^{-1}(\mathrm{Kh})=0.24027$

$\mathrm{KaG}=$

$\cos 2\left(\varphi^{\prime} \theta\right) /\left[\cos 2 \theta^{*}\{1+\right.$

$\sqrt{\left.\left(\sin \varphi^{\prime} * \sin \left(\varphi^{\prime} * \sin \left(\phi^{\prime}-\theta\right)\right) / \cos \theta\right\}\right]}=0.888$

$\Delta \mathrm{KaG}=\mathrm{KaG}-\mathrm{Ka}$

$=0.888-0.52$

$=0.367$

Koefisien tekanan tanah dinamis didapat 0.367

maka, gaya gempa arah lateral tekanan tanah dinamis adalah

MEQ $=$ TEQ $*$ YEQ $=38161.67 \mathrm{kNm}$

\section{Analisis Beban Abudment}

Setelah nilai daya dukung tanah didapat pembebanan struktur atas jembatan dihitung berdasarkan peraturan RSNI T-02-2005 tentang
Standar Pembebanan Jembatan.

\section{Data Struktur Atas}

Data struktur atas terdiri dari struktur rangka baja jembatan, lebar jembatan, tebal lantai jembatan, panjang bentang jembatan dan lain-lain, table berikut merupakan data struktur atas jembatan :

Didapatkan untuk Berat sendiri (Ms) struktur atas sebesar $3375.258 \mathrm{Kn}$.

\section{Perhitungan Design Abudment I}

Dari hasil perhitungan diatas didapatkan data dimensi abutment I yaitu tinggi 12.2 meter, panjang 11.3 meter dan lebar 10 meter, dimensi tersebut telah memenuhi control stabilitas guling arah $\mathrm{X}=4.42$ dan arah $\mathrm{Y}=5,34$ (lampiran 1.1 23), hasil perhitungan tersebut dianggap aman karena lebih besar dari Safety Factor (SF) yaitu> 2,2. Sedangkan untuk perhitungan control stabilitas geser arah $\mathrm{X}=1.38$ dan arah $\mathrm{Y}=2,13$, hasil tersebut juga aman terhadap Safety Factor (SF) yaitu $>1,1$ (lampiran 1.1 - 24)

Dari perhitungan control tersebut menjelaskan bahwa selisih angka control stabilitas guling terlalu besar terhadap factor aman> 2.2 namun diperhitungan control terhadap geser terutama arah X sudah sangat kritis terhadap factor aman sebesar 1.1

\section{Perhitungan Design Abudment II}

Dari hasil perhitungan didapatkan data dimensi abutment II yaitu tinggi 13.4 meter, panjang 12.5 meter dan lebar 10 meter, dimensi tersebut telah memenuhi control stabilitas guling arah $X=4.23$ dan arah $Y=4,93$ (lampiran 1.2 23), hasil perhitungan tersebut dianggap aman karena lebih besar dari Safety Factor (SF) yaitu> 2,2 . Sedangkan untuk perhitungan control stabilitas geser arah $\mathrm{X}=1.40$ dan arah $\mathrm{Y}=2,09$, hasil tersebut juga aman terhadap Safety Factor (SF) yaitu $>1,1$

Dari perhitungan control tersebut menjelaskan bahwa selisih angka control stabilitas guling terlalu besar terhadap factor aman> 2.2 namun diperhitungan control terhadap geser terutama arah $\mathrm{X}$ sudah sangat kritis terhadap factor aman sebesar 1.1

\section{Perhitungan Pondasi Sumuran}

Menurut Standard Perencanaan Pondasi Jembatan Departemen Pekerjaan Umum 2007, pondasi sumuran direncanakan digunakan untuk menahan gaya-gaya yang bekerja pada dasar 
pile cap sebuah abutment jembatan. Perhitungan perencanaan pondasi sumuran pada masingmasing abutment diuraikan sebagai berikut :

\section{Desain Pondasi Sumuran pada Abutment I}

Kestabilan pondasi sumuran terhadap kemungkinan terguling dihitung dengan persamaan berikut :

$$
\begin{gathered}
S F_{\text {guling }}=\frac{\sum M_{R}}{\sum M_{C}}=\frac{36661.78+23877.48}{27181.06} \\
=2.23
\end{gathered}
$$

Kohesi tanah yang diperhitungkan disini adalah kohsei tanah tepat dibawah tapak sumuran, jadi

$$
\mathrm{C}=12.26 \mathrm{kN} / \mathrm{m} 2
$$

$$
\mathrm{C} 2=0.4 \times 12.26
$$

Luas total pondasi sumuran $=2 \cdot 0 \cdot 25 \cdot \pi \cdot 3 \cdot 0^{2}=$ $14.143 \mathrm{~m} 2$

$S F_{\text {geser }}=\frac{(\Sigma v) \tan \phi_{2}+B c_{2}+P_{p}}{P_{h}}$

$=\frac{3688 \cdot \tan (15.9)+14.143 \cdot 0 \cdot 4 \cdot 12.26+7959.16}{16}$

$=17.714$

Untuk memudahkan analisis, bentuk sumuran berupa lingkaran dengan diameter $\mathrm{D}$ dapat di ekivalensikan menjadi bentuk empat persegi dengan dimensi $\mathrm{BxB}$. Besarnya nilai $\mathrm{B}$ dihitung sebagai berikut.

$\mathrm{B}=\sqrt{\left(\pi * \mathrm{D}^{2} / 4\right)}=2.659 \mathrm{~m}$

eks $=$

$\frac{B}{2}-\frac{M_{\text {net }}}{\Sigma V}=\frac{2.659}{2}-\frac{36661.78+23877.48-27181.06}{3688.00}=$ $7.715 \mathrm{~m}$

Tegangan kontak pada tanah dasar dihitung dengan persamaan :

$$
q_{\min }^{\operatorname{mak}}=\frac{\sum V}{B L}\left(1 \pm \frac{6 e k s}{B}\right)
$$

Untuk 1 pondasi suimuran nilai

$\mathrm{V}=\frac{\sum V}{B L}=\frac{3688}{2}=1844 \mathrm{kN}$

Dari perhitungan diatas dengan menggunakan 2 buah pondasi sumuran dengan diameter 3 meter dan tinggi 3.5 meter dengan daya dukung tanah $2500 \mathrm{kN}$ dapat menahan beban sendiri dan gaya diatasnya dengan factor aman geser yang cukup besar $=17.714$ namun factor aman gaya guling hanya sebesar 2.23, hal ini disebabkan beban gaya terhadap guling cukup besar seperti timbunan tanah oprit yang tinggi mencapai 12.2 meter.

\section{Desain Pondasi Sumuran pada Abutment II}

Kestabilan pondasi sumuran terhadap kemungkinan terguling dihitung dengan persamaan berikut :

$$
\begin{gathered}
S F_{\text {guling }}=\frac{\sum M_{R}}{\sum M_{C}}=\frac{46936.52+25469.31}{32328.23} \\
=2.24
\end{gathered}
$$

Kohesi tanah yang diperhitungkan disini adalah kohsei tanah tepat dibawah tapak sumuran, jadi

$$
\begin{array}{ll}
\mathrm{C} & =12.26 \mathrm{kN} / \mathrm{m} 2 \\
\mathrm{C} 2 & =0.4 \times 12.26
\end{array}
$$

Luas total pondasi sumuran $=2 \cdot 0 \cdot 25 \cdot \pi \cdot 3 \cdot 2^{2}=$ $16.091 \mathrm{~m} 2$

$S F_{\text {geser }}=\frac{\left(\sum v\right) \tan \phi_{2}+B c_{2}+P_{p}}{P_{h}}=$

$\underline{3851,68 \cdot \tan (15,9)+16,091 \cdot 0 \cdot 4 \cdot 12,26+8489,77}$

$=17.680$

Untuk memudahkan analisis, bentuk sumuran berupa lingkaran dengan diameter $\mathrm{D}$ dapat di ekivalensikan menjadi bentuk empat persegi dengan dimensi $\mathrm{BxB}$. Besarnya nilai $\mathrm{B}$ dihitung sebagai berikut.

$\mathrm{B}=\sqrt{\left(\pi * \mathrm{D}^{2} / 4\right)}=2.836 \mathrm{~m}$

eks $=$

$\frac{B}{2}-\frac{M_{n e t}}{\sum V}=\frac{2.659}{2}-\frac{46936.52+25469.31-32328.23}{3851.68}=$ $8.987 \mathrm{~m}$

Tegangan kontak pada tanah dasar dihitung dengan persamaan :

$$
q_{\min }^{\operatorname{mak}}=\frac{\sum V}{B L}\left(1 \pm \frac{6 e k s}{B}\right)
$$

Untuk 1pondasi sumuran nilai

$$
\mathrm{V}=\frac{\sum V}{B L}=\frac{3852}{2}=1925.84 k N
$$

Dari perhitungan diatas dengan menggunakan 2 buah pondasi sumuran dengan diameter 3,2 meter lebih besar dibandingkan pondasi sumuran I dan tinggi 3.5 meter dengan daya dukung tanah $2500 \mathrm{kN}$ dapat menahan beban sendiri dan gaya diatasnya dengan factor aman geser yang cukup besar $=17.680$ namun factor aman gaya guling hanya sebesar 2.24, hal ini disebabkan beban gaya terhadap guling cukup 
besar seperti timbunan tanah oprit yang tinggi mencapai 13.4 meter.

\section{KESIMPULAN}

Kesimpulan yang dapat diambil dari hasil analisis dan perhitungan yang telah dilakukan pada penelitian ini antara lain :

Pada Penelitian ini didapatkan hasil dimensi abudment sesuai dengan pengukuran topografi dan beban data struktur atas maka didapatkan dimensi abudment I dengan tinggi 12,2 meter, panjang 10 meter dan lebar 11,3 meter sedangkan abudment II dengan tinggi 13,4 meter, panjang 10 meter dan lebar 12,5 meter.

Pada Penelitian ini didapatkan hasil dimensi pondasi sumuran sesuai dengan hasil uji sondir dengan daya dukung $2500 \mathrm{Kn}$ di kedalaman 5 meter dan hand boring dengan berat jenis tanah $1,441 \mathrm{Gr} / \mathrm{cm} 3$, sudut geser $15,87^{\circ}$ dan Kohesi sebesar $0,125 \mathrm{Kg} / \mathrm{cm} 2$ maka didapatkan dimensi pondasi sumuran I dengan tinggi 3,5 meter dan lebar 3,0 meter dengan jumlah pondasi 2 buah sedangkan dimensi pondasi sumuran I dengan tinggi 3,5 meter dan lebar 3,2 meter dengan jumlah pondasi 2 buah.

\section{DAFTAR PUSTAKA}

[1] Aji S, Tri KH. 2017. Perancangan Bangunan Sipil Jembatan Sigandul II. Laporan Tugas. Tidak Diterbitkan. Fakultas Teknik. Universitas Diponegoro: Semarang

[2] Departemen Pekerjaan Umum, 1987. Pedoman Perencanaan Pembebanan Jembatan Jalan Raya.

[3] Departemen Pekerjaan Umum 1992. Bridge Management System.

[4] Departemen Pekerjaan Umum 2007. Manual Petunjuk Teknis Pengujian Tanah.

[5] Departemen Pekerjaan Umum 2007. Perencanaan Pondasi Jembatan.

[6] Hiram MD. 2008. Perencanaan Jembatan Rangka Baja Sungai Ampel Kebupaten Pekalongan. Tugas Akhir. Tidak Diterbitkan. Fakultas Teknik Sipil. Universitas Katolik Soegijapranata: Semarang

[7] Iman S. 1979. Jembatan Baja. Idea Dharma: Bandung

[8] Standar Nasional Indonesia 2004. SNI T12-2004. Perencanaan Struktur Beton untuk Jembatan. Badan Standardisasi Nasional.

[9] Standar Nasional Indonesia 2005. RSNI T-
02-2005. Standar Pembebanan untuk Jembatan. Badan Standardisasi Nasional.

[10] Standar Nasional Indonesia 2008. SNI 2883:2008. Standar Perencanaan Ketahanan Gempa untuk Jembatan. Badan Standardisasi Nasional.

[11] Virgo EP. 2013. Kajian Pemilihan Pondasi Sumuran sebagai Alternatif Perancangan Pondasi. Tidak Diterbitkan. Fakutas Teknik Sipil.Universitas Simalungun: Pematang Siantar.

[11] Zulkifli F. 2014. Analisis Struktur Pondasi dan Abutment Jembatan pada Proyek Jalan Tol Cimanggis-Cibitung. Tidak Diterbitkan. Fakutas Teknologi Pertanian. Institut Pertanian Bogor : Bogor 